\title{
Assessors reports on Advisory Appointments Committees Changes since 1974
}

\author{
Peter Brook, Consultant Psychogeriatrician, Fulbourn Hospital, Cambridge
}

From the time of its foundation the College has been represented on Advisory Appointments Committees for consultant posts. One of the College nominated assessors' responsibilities is to supply confidential information on applicants, and those interviewed, to the Registrar by completing a form containing information on the number of applicants, numbers interviewed and their quality together with any deficiencies in qualifications and experience in those seen and those appointed. Prior to 1979 the assessors gave their opinion on qualifications and experience on all applicants but the form then in use did not allow for any quantitative analysis. Since the introduction of a new form in that year, such an analysis has been possible. A summary of assessors reports from 1974 to 1977 was published in the Bulletin. ${ }^{1}$

An analysis has now been made of 995 returns (a $69 \%$ response rate) from England and Wales for the years 1980-86 inclusive, covering all psychiatric specialities. However, substance abuse has not been analysed because of very small numbers in post and community psychiatry and rehabilitation have been included in the figures for general psychiatry.

\section{The findings}

Table I gives figures for the total number of posts for each specialty, the number of times when no appointment was made and the number of times where reservations were expressed about candidates who were appointed: the 1974/1977 results are included for comparison. Frequently the reservations were solely that the appointee had held a senior registrar post for less than the recommended minimum of three years but sometimes other and more serious reservations were expressed.

The first-and most striking feature-is the increase in the number of consultant posts over the years: this is particularly so for psychogeriatrics.

In general psychiatry there has been a diminution overall in the frequency where no appointment was made (either because no candidate appeared or none were considered suitable) and fewer occasions where reservations were expressed about successful candidates except for a marked rise in 1986. Similarly in psychogeriatrics and child psychiatry there has been a substantial falling off in the numbers where reservations have been expressed but the reverse holds true of psychotherapy and forensic psychiatry.

Tables II and III show assessors' opinions on the overall quality of candidates interviewed and include the figures for 1974/1977 for comparison.

For general psychiatry, because of the large number of candidates, the figures for 1980/86 are given separately for each year in addition to the total for the whole period. There have been fluctuations over time but overall the proportion of very good and good candidates interviewed has increased sharply with a corresponding diminution in the proportion of average and indifferent and poor candidates. Psychogeriatrics has also shown a substantial rise in very good and good interviewees, largely at the expense of the average group, while the proportion of indifferent and poor candidates has risen slightly. Child psychiatry has changed little, retaining a high proportion of good quality interviewees, but psychotherapy and forensic psychiatry have apparently lost ground but even so the proportions of very good and good psychotherapy interviewees are still comparable to general and child psychiatry and higher than other specialties. There has been no change in mental handicap and the proportions of very good and good candidates are lower in this field than in any other specialty. The same overall comments apply also to the ratings of the experience of candidates.

\section{Comment}

Although the form was revised in 1979 by the present author it remains deficient in one important respect, namely that no attempt was made to define the qualities 'qualifications' and 'experience'. The figures suggest that by and large assessors treated these two qualities in a similar fashion.

For the specialties of psychotherapy and forensic psychiatry the relatively small numbers involved make it difficult to be certain about changes over time.

At first sight the results cast doubts on the effectiveness of the College and the JCHPT in improving the numbers of good quality applicants for consultant posts since their formation respectively in 1971 and 
TABLE I

Advisory Appointments Committees Analysis 1980-86

\begin{tabular}{|c|c|c|c|c|c|}
\hline General psychiatry & $\begin{array}{c}\text { Number of } \\
\text { posts }\end{array}$ & \multicolumn{2}{|c|}{$\begin{array}{l}\text { Number }(+\%) \text { where } \\
\text { no appointment made }\end{array}$} & \multicolumn{2}{|c|}{$\begin{array}{c}\text { Number (+\% of filled posts) } \\
\text { where reservations expressed } \\
\text { about successful candidates }\end{array}$} \\
\hline $\begin{array}{l}\text { General psychiatry } \\
1974-77 \\
1980-81 \\
1982-83 \\
1984-85 \\
1986 \\
1980-86\end{array}$ & $\begin{array}{r}173 \\
124 \\
90 \\
118 \\
54 \\
586\end{array}$ & $\begin{array}{r}40 \\
33 \\
15 \\
25 \\
5 \\
78\end{array}$ & $\begin{array}{l}(23.1 \%) \\
(26.6 \%) \\
(16.7 \%) \\
(21.2 \%) \\
(10.8 \%) \\
(20.2 \%)\end{array}$ & $\begin{array}{r}15 \\
8 \\
3 \\
4 \\
7 \\
72\end{array}$ & $\begin{array}{l}(11.3 \%) \\
(8.8 \%) \\
(4 \%) \\
(4.3 \%) \\
(14.3 \%) \\
(7.1 \%)\end{array}$ \\
\hline $\begin{array}{l}\text { Child psychiatry } \\
1974-77 \\
1980-86\end{array}$ & $\begin{array}{r}84 \\
192\end{array}$ & $\begin{array}{l}11 \\
41\end{array}$ & $\begin{array}{l}(13.1 \%) \\
(21.4 \%)\end{array}$ & $\begin{array}{l}15 \\
13\end{array}$ & $\begin{array}{l}(20.5 \%) \\
(8.6 \%)\end{array}$ \\
\hline $\begin{array}{l}\text { Psychogeriatrics } \\
1974-77 \\
1980-86\end{array}$ & $\begin{array}{r}31 \\
174\end{array}$ & $\begin{array}{l}10 \\
51\end{array}$ & $\begin{array}{l}(32 \%) \\
(29.3 \%)\end{array}$ & $\begin{array}{r}8 \\
24\end{array}$ & $\begin{array}{l}(38 \%) \\
(19.5 \%)\end{array}$ \\
\hline $\begin{array}{l}\text { Mental handicap } \\
1974-77 \\
1980-86\end{array}$ & $\begin{array}{r}57 \\
143\end{array}$ & $\begin{array}{l}24 \\
54\end{array}$ & $\begin{array}{l}(42.1 \%) \\
(37.8 \%)\end{array}$ & $\begin{array}{r}6 \\
17\end{array}$ & $\begin{array}{l}(18.2 \%) \\
(19.1 \%)\end{array}$ \\
\hline $\begin{array}{l}\text { Psychotherapy } \\
1974-77 \\
1980-86\end{array}$ & $\begin{array}{l}26 \\
49\end{array}$ & $\begin{array}{l}2 \\
7\end{array}$ & $\begin{array}{r}(7.7 \%) \\
(14.3 \%)\end{array}$ & $\begin{array}{r}3 \\
11\end{array}$ & $\begin{array}{l}(12.5 \%) \\
(26.2 \%)\end{array}$ \\
\hline $\begin{array}{l}\text { Forensic psychiatry } \\
1974-77 \\
1980-86\end{array}$ & $\begin{array}{l}13 \\
51\end{array}$ & $\begin{array}{r}2 \\
12\end{array}$ & $\begin{array}{l}(15.4 \%) \\
(23.5 \%)\end{array}$ & $\begin{array}{r}0 \\
15\end{array}$ & $(38.5 \%)$ \\
\hline
\end{tabular}

1974; a number of factors must be taken into account before adopting such a pessimistic viewpoint.

First, there has been the need to generate large numbers of well qualified candidates for a rapidly expanding specialty. The College has contended in its submission to the Joint Planning Advisory Committee (JPAC) that the number of higher training posts has been insufficient to match consultant vacancies. ${ }^{2}$ This mismatch would account in large measure for the failure to fill posts, reservations about successful candidates and the large numbers of insufficiently qualified and experienced applicants demonstrated in the assessors' reports. It would also explain the fact that some of these applicants had obtained the MRCPsych but failed to obtain senior registrar posts, (because of the discrepancy in numbers between registrars and senior registrars), often being forced in consequence into a succession of locum jobs rather than proceeding to approved higher training.
A second factor has been the even more rapid expansion in the numbers of consultants in certain specialties such as psychogeriatrics which has not been matched by an increase in the number of appropriate training placements. ${ }^{3}$ This again, would lead to difficulty in filling posts, together with the appointment of relatively inexperienced candidates and a general low level of applicants.

JPAC has accepted and acted on the College's arguments that more senior registrar posts are needed in general psychiatry (with a particular emphasis on psychogeriatrics and substance abuse) child psychiatry and psychotherapy by sanctioning an increase in the numbers of senior trainees. JPAC has still to consider the number of senior registrars in forensic psychiatry and handicap in the light of the Colleges' submission.

A third and paradoxical factor is that standards of training both at general professional and higher levels have undoubtedly been greatly raised by the 
TABLE II

Quality of candidates interviewed-general psychiatry (Number and percentages rounded)

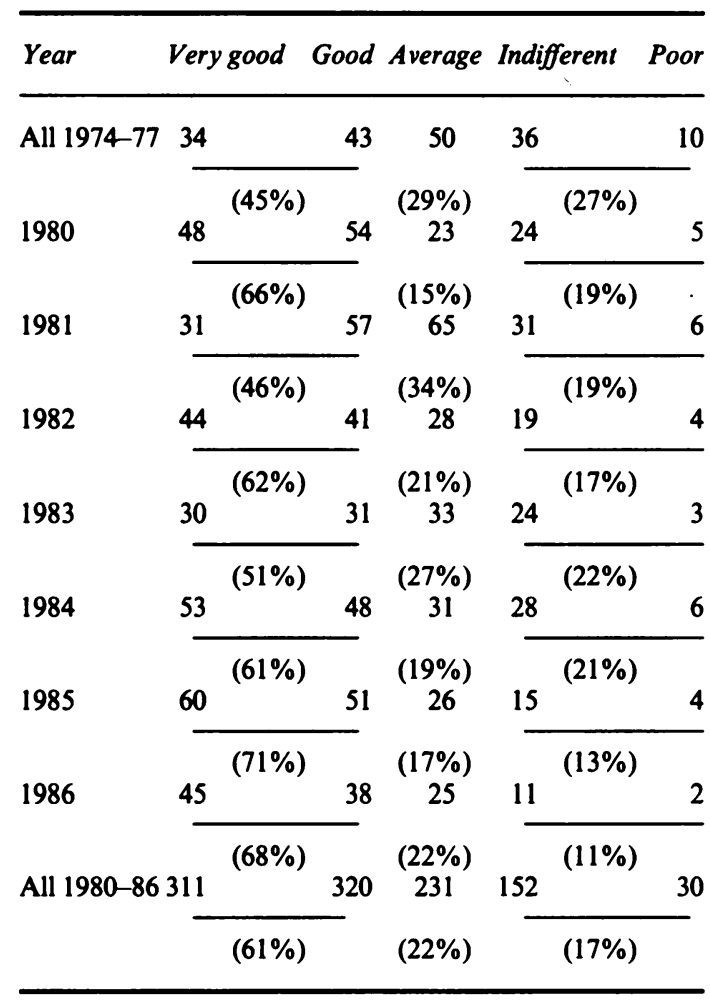

College and JCHPT with the consequence that assessors' expectations have been correspondingly raised so that the 'good' candidate of the 1970s might be seen as only 'average' in the 1980 s.

A fourth factor is that advertised posts were adversely commented on by assessors in terms of their being poorly resourced; this comment was made frequently in the field of psychogeriatrics most especially in the earlier years. The result would be that the best applicants, aware of these deficiencies, might well withdraw their applications thus leaving only indifferent candidates or none at all.

Finally, another factor influencing these results would be that, until recently, mental handicap and forensic psychiatry have been unpopular specialities so that available senior registrar posts have not been filled, resulting in a dearth of applicants for consultant posts. This trend has recently been sharply reversed in forensic psychiatry, with a fall in the percentage of senior registrar posts not permanently filled from $29 \%$ in 1984 to only $9 \%$ in 1986 . Handicap was, until recently, an unpopular specialty in these terms with $24 \%$ of posts not filled permanently in 1984 but dropping to $19 \%$ in 1986 and there are good indications that a further drop has taken place in the last year. In comparison mental illness, child psychiatry and psychotherapy have some $8-10 \%$ only of senior registrars not permanently filled. 4.5

The assessors' reports reflect in part therefore the problems produced by a rapidly expanding specialty, which embraces even more rapidly expanding subspecialties, compounded by a marked inbalance between the numbers of registrars and senior registrars, a situation which should be relieved by the implementation of the recommendations in Achieving a Balance. ${ }^{6}$ In addition, psychiatric specialties remain less popular than others and there are inadequate numbers of higher training posts in psychogeriatrics, a relatively new and very rapidly expanding specialty. Having made these points

TABLE III

Quality of candidates interviewed-psychiatric specialties (Percentages rounded)

\begin{tabular}{|c|c|c|c|c|c|}
\hline $\begin{array}{l}\text { Specialty } \\
\text { and year }\end{array}$ & $\begin{array}{l}\text { Very } \\
\text { good }\end{array}$ & Good & Average & $\begin{array}{l}\text { Indif- } \\
\text { ferent }\end{array}$ & Poor \\
\hline $\begin{array}{l}\text { Child psychiatry } \\
\text { 1974-77 }\end{array}$ & 13 & 37 & 19 & 10 & 3 \\
\hline \multirow[t]{2}{*}{$1980-86$} & $109^{(6}$ & 143 & $\begin{array}{c}(23 \%) \\
107\end{array}$ & $43^{(18}$ & 16 \\
\hline & & & $(26 \%)$ & & $\%)$ \\
\hline \multirow[t]{2}{*}{$\begin{array}{l}\text { Psychogeriatrics } \\
1974-77\end{array}$} & 3 & 3 & 13 & 4 & 3 \\
\hline & & 96 & $\begin{array}{c}(42 \%) \\
75\end{array}$ & $56^{(23}$ & \%) 43 \\
\hline $1980-86$ & & & $(22 \%)$ & & \\
\hline $\begin{array}{l}\text { Handicap } \\
1974-77\end{array}$ & 7 & 13 & 13 & 12 & 12 \\
\hline \multirow[t]{2}{*}{$1980-86$} & $46^{(3}$ & \%) 49 & $\begin{array}{c}(23 \%) \\
86\end{array}$ & $72^{(42}$ & \%) 44 \\
\hline & & & $(29 \%)$ & & \\
\hline $\begin{array}{l}\text { Psychotherapy } \\
1974-77\end{array}$ & 8 & 11 & 4 & 2 & 1 \\
\hline \multirow[t]{2}{*}{$1980-86$} & $29^{(7}$ & 49 & $\begin{array}{c}(15 \%) \\
35\end{array}$ & $11^{(12}$ & \%) 10 \\
\hline & & & $(26 \%)$ & & $\%)$ \\
\hline $\begin{array}{l}\text { Forensic } \\
1974-77\end{array}$ & 3 & 5 & 4 & 0 & 1 \\
\hline \multirow[t]{2}{*}{$1980-86$} & $23^{(6}$ & \%) 20 & $\begin{array}{c}(31 \%) \\
13\end{array}$ & $21^{(8}$ & \%) 18 \\
\hline & & & $(14 \%)$ & & $\%)$ \\
\hline
\end{tabular}


TABLE IV

Qualification of applicants 1980-86 (Percentages rounded)

\begin{tabular}{lccc}
\hline Specialty & $\begin{array}{c}\text { Very good } \\
\text { and good }\end{array}$ & Average & $\begin{array}{c}\text { Indifferent } \\
\text { and poor }\end{array}$ \\
\hline $\begin{array}{l}\text { General psychiatry } \\
(N=2374)\end{array}$ & 44 & 46 & 10 \\
$\begin{array}{l}\text { Child psychiatry } \\
(N=642)\end{array}$ & 58 & 33 & 9 \\
$\begin{array}{l}\text { Psychogeriatrics } \\
(N=677)\end{array}$ & 43 & 33 & 23 \\
$\begin{array}{l}\text { Mental handicap } \\
(N=530)\end{array}$ & 31 & 33 & 36 \\
$\begin{array}{l}\text { Psychotherapy } \\
(N=233)\end{array}$ & 45 & 39 & 15 \\
$\begin{array}{l}\text { Forensic psychiatry } \\
(N=164)\end{array}$ & 29 & 12 & 59 \\
\hline
\end{tabular}

TABLE V

Experience of applicants 1980-86 (Percentages rounded)

\begin{tabular}{lccc}
\hline Specialty & $\begin{array}{c}\text { Very good } \\
\text { and good }\end{array}$ & Average & $\begin{array}{c}\text { Indifferent } \\
\text { and poor }\end{array}$ \\
\hline $\begin{array}{l}\text { General psychiatry } \\
(N=2374)\end{array}$ & 48 & 34 & 17 \\
$\begin{array}{l}\text { Child psychiatry } \\
(N=642)\end{array}$ & 61 & 25 & 15 \\
$\begin{array}{l}\text { Psychogeriatrics } \\
(N=677)\end{array}$ & 35 & 31 & 35 \\
$\begin{array}{l}\text { Mental handicap } \\
(N=530)\end{array}$ & 32 & 30 & 39 \\
$\begin{array}{l}\text { Psychotherapy } \\
(N=233)\end{array}$ & 42 & 33 & 24 \\
$\begin{array}{l}\text { Forensic psychiatry } \\
(N=164)\end{array}$ & 28 & 16 & 55 \\
\hline
\end{tabular}

however, there must still be concern about standards of training which will continue to need attention both of the College and JCHPT through their inspections and visitations. The vigilance of College advisers on assessment committees offers an important opportunity for monitoring standards of training and the data they provide on candidates and posts should continue to be collected and assessed by the College.

\section{Acknowledgements}

I am grateful to all those assessors who completed and returned their forms, to Mrs Jane Hinton for collating them and to the President-Dr James Birley - and the Dean - Professor Andrew Sims - for their helpful comments. I am deeply in Dr Garry Blessed's debt for his putting up a number of hypotheses explored in the paper and for detailed-and invariably helpful - comments on the paper.

\section{References}

${ }^{1}$ Brook, P. (1979) Assessors reports on advisory appointments committees. Bulletin of the Royal College of Psychiatrists, 3, 1-10.

${ }^{2}$ BewLeY, T. H. (1987) Joint Planning Advisory Committee. Report of Meeting 14 October 1986. Bulletin of the Royal College of Psychiatrists, 11, 72.

${ }^{3}$ BLESSED, G. (1986) Survey into the availability of Higher Specialist Training in the Psychiatry of Old Age. Bulletin of the Royal College of Psychiatrists, 10, 88-90.

${ }^{4}$ DHSS (1983) Statistics and research division. Hospital medical staff. England and Wales. National tables. 1983.

5 _ (1987) Medical and dental staffing prospects in the NHS in England and Wales 1986. Health Trends, 19, $1-8$.

${ }^{6}$ SteERING Group (1987) Hospital Medical Staffing. Achieving a Balance. Plan for Action. London: DHSS. 